\title{
IbM TERONG VIRUS DI KECAMATAN KAYU ARO KABUPATEN KERINCI, JAMBI
}

\author{
Edison dan Riri Oktari Ulma \\ Fakultas Pertanian Universitas Jambi \\ Email: ediedison950@yahoo.co.id; ririoktariulma@gmail.com
}

\begin{abstract}
ABSTRAK
Melalui pengembangan agroindustri jus terong virus mulai dari skala kecil sampai skala menengah dipedesaan diharapkan akan dapat menciptakan mata rantai agribisnis jus terong virus yang kuat dengan memberikan dampak mempercepat pengembangan perekonomian pedesaan seperti teknologi pascapanen terong virus untuk meningkatkan pendapatan petani terong virus. Kegiatan pengabdian kepada masyarakat ini bertujuan agar : (a) petani terong virus memiliki pengetahuan tentang teknologi pascapanen, (b) menguasai teknik pembuatan jus terong virus, (c) terampil membuat jus terong virus. Juga dengan kegiatan ini diharapkan akan diperoleh manfaat sebagai berikut : (a) sebagai upaya peningkatan teknologi pascapanen terong virus untuk memperoleh bahan baku yang baik, (b) memiliki profesi dibidang agroindustri khususnya jus terong virus sehingga memberikan peluang tambahan penghasilan, dan (c) penyebarluasan IPTEKS sebagai produk yang perlu diketahui dan dimanfaatkan. Dalam melaksanakan kegiatan ini, dibagi menjadi 4 bagian yaitu penyuluhan, kunjungan lapang, praktek dan konsultasi lapang. Kegiatan dilaksanakan di Desa Sako Duo Kecamatan Kayu Aro Kabupaten Kerinci Jambi mulai Maret 2017 sampai dengan Nopember 2017. Khalayak sasaran kegiatan pengabdian ini adalah petani terong virus, ibuibu PKK yang merupakan anggota Kelompok Tani Arimbi dan Rahma Putri Desa Sako Duo Kebun Baru, Kecamatan Kayu Aro, Kabupaten Kerinci, Jambi. Mengingat keterbatasan ruang dan waktu yang tersedia, jumlah peserta yang ikut dalam kegiatan ini sebanyak 65 orang. Dari hasil kegiatan pengabdian kepada masyarakat ini dapat disimpulkan sebagai berikut (a). Upaya peningkatan pendapatan petani terong virus dapat dilakukan dengan penerapan teknologi agroindustri jus terong virus dengan mengolah terong virus menjadi jus terong virus. (b). Memotivasi peserta kegiatan untuk mengetahui budidaya terong virus dan teknologi pascapanen terong virus ini cukup baik, yang ditandai dengan peningkatan evaluasi akhir dari evaluasi akhir dengan tingkat perbedaan yang nyata.
\end{abstract}

\section{Kata Kunci : IbM, Terong Virus, Jus Terong Virus, Agribisnis dan Agroindustri}

\section{PENDAHULUAN}

Dalam melaksanakan pembangunan pertanian dengan sistim agribisnis tersebut di Jambi, kegiatannya dipilah menjadi beberapa kawasan sentra produksi. Salah satu komoditi unggulan khususnya di Kabupaten Kerinci yang telah menjadi primadona untuk meningkatkan kesejahteraan masyarakat adalah tanaman hortikultura. Kabupaten Kerinci sama seperti Kabupaten lainnya, masih didominasi oleh kegiatan pertanian. Sedangkan komoditi hortikultura telah memberikan kontribusi yang cukup besar bagi PDRB Kabupaten Kerinci yakni sebesar 14,5\% pada tahun 2011 (Bappeda Kerinci, 2014).

Untuk melakukan kegiatan pengembangan manajemen agribisnis dan agro industri jus terong virus, digunakan metode pendekatan partisipatif. Dalam kaitannya untuk melakukan kegiatan pengembangan manajemen agribisnis dan agroindustri jus terong virus digunakan metode pendekatan partisipatif. Dalam kaitannya dengan tujuan kegiatan yakni 
untuk pengembangan pengelolaan usahatani dan pemasaran terong virus yang efisien, paradigma baru pendekatan pembangunan pertanian bersifat people-centered, participatory, empowering, and sustainable digunakan. Dengan demikian keempat sifat tersebut seyogyanya menjadi landasan dalam setiap program pembangunan agribisnis yang hendak dilakukan. Dalam bentuk yang lebih sederhana, keempat sifat tersebut dapat diramu menjadi dua kata kunci, yaitu pemberdayaan dan partisipasi masyarakat. Pemberdayaan terkandung makna keberpihakan. Artinya, kekuatan (daya) yang berasal dari dan dimiliki oleh masyarakat dicoba diperkuat dengan unsur-unsur dari luar, sehingga dihasilkan kekuatan yang lebih besar untuk mencapai sesuatu yang dikehendaki. Karena pengembangan masyarakat melibatkan unsur norma dan perilaku orang-orang, maka sebenarnya sisi yang hendak dicapai adalah pengembangan kelembagaan yang terdiri dari dua bagian besar yaitu organisasi dan aturan main (Helmi, 2008 dan Soekartawi, 2006).

Dalam pembangunan berbasis komunitas lokal, sumberdaya yang tersedia di masyarakat, baik sumberdaya finansial maupun sumberdaya non-finansial dapat dimanfaatkan secara lokal menurut kebutuhan setempat. Hal ini dimungkinkan karena kebutuhan pembangunan dapat diprioritaskan sesuai dengan kebutuhan riil, Komunitas atau masyarakat lokal yang diikutsertakan dalam proses pengambilan keputusan dan implementasinya akan lebih responsive untuk turut memikul tanggung jawab pengelolaan pelaksanaan kegiatan. Hal ini akan membantu mengurangi biaya yang perlu disediakan pihak pemerintah. Disamping itu pengetahuan dan keterampilan lokal (indigenous technical know- how) mampu diadaptasikan untuk membantu penghematan biaya dan peningkatan keuntungan (Helmi, 2008). Pemikiran diatas secara eksplisit menggambarkan keikutsertaan masyarakat sebagai mitra pembangunan, dan bukan lagi sebagai kelompok sasaran. Dalam keadaan ini partisipasi masyarakat sangat dibutuhkan, terutama dalam bentuk partisipasi yang bersifat mobilisasi spontan yang diartikan secara positif (Susanti, 2003).

Salah satu komoditi hortikultura yang banyak diusahakan di Kabupaten Kerinci, khususnya di Kecamatan Kayu Aro adalah terong virus. Luas areal yang ditanami terong virus seluas 23 hektar. Hampir semua tanaman dilakukan dengan cara bercocok tanam secara sederhana yakni disebagian tanaman utama. Produksi terong virus pada tahun 2014 sebanyak 3,7 ton (Bappeda Kerinci, 2015).

Terong virus sebagai salah satu produk pertanian yang mendapat prioritas dengan meningkatnya produksi dan tumbuhnya industri pengolahan pangan karena mendatangkan keuntungan bagi petani, terutama dalam rangka meningkatkan pendapatan petani. Bermacam-macam produk olahan terong virus telah dikembangkan seperti jus terong virus. Jus terong virus merupakan produk olahan makanan ringan yang banyak manfaatnya sebagai tambahan makanan ringan. Pengolahannya sangat sederhana, memerlukan biaya yang relatif rendah sehingga dapat memenuhi kebutuhan rumah tangga dan membuka peluang bagi industri kecil. Teknologi pascapanen dan pembuatan pangan merupakan alternatif yang bermanfaat dan sekaligus menjadi arah pembangunan nasional dalam menciptakan sumberdaya yang terampil.

Produksi terong virus banyak dijual dalam bentuk produk yang belum diolah, yang mengakibatkan terjadinya ketimpangan dalam bentuk penentuan harga bila terjadi panen 
raya. Petani terong virus dahulunya banyak yang menggantungkan hasil terong virus nya pada pedagang perantara yang nakal (tengkulak), sehingga hasil yang diperoleh juga relatif tidak sebanding dengan yang seharusnya. Upaya untuk memutus mata rantai dengan tengkulak ini sudah berjalan beberapa tahun belakangan ini seperti membentuk kelompokkelompok ekonomi namun masih terkendala. Beberapa permasalahan yang banyak ditemui adalah aspek budidaya yang kurang baik, pengelolaan usaha yang kurang efisien, dan masih belum terbiasanya melakukan kegiatan agroindustri yang baik. Sehingga dalam rangka untuk mengatasi masalah tersebut dan meningkatkan pendapatan petani terong virus, kegiatan pengabdian ini perlu dilakukan untuk mendapatkan nilai tambah dari produksi terong virus nya dengan melakukan upaya pembekalan manajemen usaha yang baik dan pengolahan jus terong virus. Ada beberapa kelompok tani terong virus di Kecamatan Kayu Aro Kabupaten Kerinci. Kelompok tani Arimbi dan Rahma Putri dipilih untuk dijadikan mitra kegiatan, karena luas areal tanaman terong virus yang dimilikinya cukup luas yakni 23 hektar, dan juga jumlah petani yang termasuk dalam kelompok tani Arimbi dan Rahma Putri sebanyak 98 KK (Edison, 2013).

Kelompok tani terong virus sendiri belum menikmati hasil yang telah dicapai tersebut. Menurut Soedaryanto dan Jamal (2005) dan Taher (2005) ada beberapa hal yang menjadi masalah utama yang dihadapi kelompok tani yaitu (a) belum efisiennya kelompok tani dalam mengelola usahanya; dan (b) belum diupayakannya mencari hasil alternatif yang dapat memberikan nilai tambah yang lebih baik.

Universitas Jambi dengan visi dan misinya yang jelas untuk berperan serta dalam pembangunan daerah Jambi, bertanggung jawab terhadap pembangunan Jambi pada umumnya, meningkatkan kesejahteraan masyarakat pada khususnya. Melalui Tridharma Perguruan Tinggi, Universitas Jambi (a) tidak hanya menghasilkan lulusan yang kompeten dalam bidang ilmunya, namun juga lulusan yang dapat menjadi wirausahawan yang menjadi pelopor dan penggerak pembangunan di daerah Jambi, (b) harus menjalankan peran dan fungsi sebagai agen transformasi budaya melalui penyebaran gagasan-gagasan baru kepada masyarakat dan menjadi jembatan antara pengembangan ilmu pengetahuan dan teknologi (IPTEK) dan penerapannya oleh masyarakat, (c) diharapkan dapat berperan secara aktif dalam memecahkan berbagai masalah yang dihadapi dalam pembangunan daerah (Universitas Jambi, 2013).

Dengan melihat peran serta dan tanggung jawab Universitas Jambi terhadap pembangunan daerah Jambi pada umumnya dan peningkatan pendapatan petani di Kabupaten Kerinci pada khususnya, dengan ini kami tim kecil Fakultas Pertanian ingin melakukan kegiatan dalam upaya peningkatan pendapatan pengusahaan jus terong virus di Kabupaten Kerinci yakni (a) kegiatan pengembangan pengelolaan usaha terong virus yang efisien; dan (b) kegiatan teknologi pascapanen dan pengolahan terong virus yang lebih baik.

\section{TARGET DAN LUARAN}

Dari hasil kegiatan ini diharapkan akan diperoleh solusi dan target luaran sebagai berikut :

- Bagi kelompok tani, mereka memperoleh pengetahuan dan keterampilan tentang pengelolaan atau teknik penanganan pascapanen dan pengolahan jus terong virus, 
untuk memperoleh hasil terong virus yang baik dan dapat mengolahnya menjadi produk olahan yaitu jus terong virus. Dan juga nantinya memilih profesi dibidang agroindustri khususnya jus terong virus, sehingga memberi peluang tambahan pendapatan. Indikator keberhasilan dapat dilihat dari berapa banyak bidang usaha yang akan dikerjakan dari kegiatan pengebdian seperti mengusahakan usahatani terong virus dengan produksi yang semakin meningkat, memperlakukan produk terong virus sebagai bagian dari agroindustri jus terong virus, dan juga berapa banyak jenis produk jus terong virus yang akan mampu dihasilkan.

- Bagi Universitas Jambi yang mempunyai peran dan fungsi sebagai agen transformasi, kegiatan ini merupakan pemberian informasi kepada masyarakat dalam menyebarluaskan IPTEKS sebagai produk yang perlu diketahui dan dimanfaatkan.

- Disamping itu diharapkan kegiatan ini memperoleh hasil tulisan ilmiah yang dipublikasikan di jurnal pengabdian kepada masyarakat.

- Bagi pelaksana bisa menjadi pemakalah dalam pertemuan ilmiah, dan untuk menemukan teknologi tepat guna.

\section{METODE PELAKSANAAN}

\section{Tempat dan Waktu Pelaksanaan}

Pengabdian dilakukan di Desa Sako Duo Kecamatan Kayu Aro Kabupaten Kerinci. Penentuan lokasi dilakukan dengan sengaja (purposive) dengan pertimbangan bahwa lokasi tersebut merupakan salah satu sentra produksi terong virus di Jambi dan di Kabupaten Kerinci khususnya Pengabdian dilaksanakan pada tahun 2017.

\section{Metode Pelaksanaan}

Dalam kaitannya dengan pelaksanaannya, kegiatan ini akan dilakukan dengan beberapa cara yakni (a) Penyuluhan, (b) Kunjungan Lapang, (c) Konsultasi, dan (d) Praktek.:

(a) Penyuluhan. Kegiatan penyuluhan meliputi ceramah dan diskusi didalam balai pertemuan. Pada kegiatan ini terjadi alih pengetahuan dari penyuluh kepada khalayak sasaran. Oleh karenanya dalam kegiatan ceramah dan diskusi peserta dibekali modul dari kegiatan yang akan dilaksanakan. Apabila dari modul dan penjelasan lisan masih ada hal-hal yang belum jelas dapat ditanyakan pada saat diskusi.

(b) Kunjungan Lapang. Tim kecil bersama-sama dengan peserta kegiatan meninjau lokasi pertanaman dan laboratorium manajemen pertanian yang menjadi landasan untuk kegiatan usahatani dan pemasaran yang efisien. Tim menjelaskan kepada peserta tentang berusahatani dan pemasaran hasil yang efisien yang pada akhirnya akan meningkatkan pendapatan.

(c) Konsultasi. Setelah kegiatan praktek dilakukan kunjungan lapang, kembali untuk melihat kelanjutan kegiatan dan sekaligus untuk mengatasi kesulitan para peserta tentang materi yang diberikan. Dalam kegiatan ini khalayak sasaran dilibatkan secara langsung sehingga dapat belajar sambil bekerja.

(d) Praktek. Praktek kegiatan pengembangan pengelolaan usahatani dan pemasaran terong virus yang efisien dilaksanakan di Balai Desa dan Laboratorium Manajemen Pertanian. Pertemuan oleh tim kecil memperagakan pengelolaan usahatani dan pemasaran hasil yang efisien berlandaskan pada spesifik lokasi dan konsep nilai 
tambah. Dan selanjutnya memberikan kesempatan kepada peserta untuk mendapatkan pengalaman untuk mengelola usahatani dan memasarkan hasilnya se efisien mungkin.

Sedangkan model yang akan diberikan pada kegiatan tersebut sebagai berikut :

1. Permasalahan dalam Pengelolaan Perusahaan dan Pemasaran yang Efisien

2. Skenario Pengembangan Pengelolaan Perusahaan dan Pemasaran yang Efisien

3. Model Sinergi Produksi Usaha Terpadu

4. Model Sinergi Usaha yang Efisien

5. Mekanisme Operasional Pengelolaan Usahatani dan Pemasaran yang Efisien.

Selanjutnya untuk melakukan kegiatan teknologi pascapanen dan pengolahan jus terong virus menurut Susanto dan Saneto, 2003). digunakan metode sebagai berikut : peningkatan pendapatan petani terong virus akan sangat terbantu apabila dilakukan perbaikan teknologi pascapanen yang tepat. Selain itu hasil terong virus yang melimpah tersebut harus diupayakan untuk tidak dijual seluruhnya dalam bentuk segar tetapi diolah menjadi produk yang bernilai ekonomis tinggi. Untuk itu kegiatan ditekankan pada penanganan pascapanen dan pengolahannya. Salah satu cara untuk meningkatkan nilai tambah yang besar dari hasil terong virus tersebut adalah dengan mengolahnya menjadi produk jus terong virus. Pembuatan jus terong virus sangat sederhana, mudah dipelajari dan dilaksanakan. Disamping itu teknologi pembuatan jus terong virus memerlukan biaya yang relatif murah sehingga dapat dilakukan dan dicobakan dalam skala industri kecil rumah tangga sebelum akhirnya menjadi produk ekspor (Renate, 2004). Faktor-faktor penting yang perlu diperhatikan apabila ingin memulai industri kecil adalah pemilihan varitas, budidaya, panen dan pascapanen sampai pada tataniaga terong virus. Pascapanen merupakan kegiatan seleksi mutu dan penyimpanan. Pascapanen berhubungan langsung dengan kualitas bahan baku yang akan diolah. Dengan kata lain, bahan baku merupakan penentu kualitas jus terong virus disamping metode pembuatan yang baik. Menurut Susanto dan Saneto (2003) terong virus yang akan diolah menjadi jus terong virus diharapkan mempunyai kadar gula reduksi yang rendah sehingga dapat dihindari hasil yang jelek. Metoda pembuatan jus terong virus juga memerlukan pengetahuan khusus mulai dari sortasi bahan baku sampai ke hasil sehingga dihasilkan jus terong virus yang berkualitas. Oleh sebab itu dalam kegiatan ini akan dilakukan percobaan pembuatan jus terong virus di laboratorium menggunakan terong virus varietas Kerinci yaitu jenis terong virus yang diusahakan oleh petani terong virus di Kabupaten Kerinci.

Kegiatan pengabdian yang akan dilakukan di lapangan, berupa kegiatan yang dibagi menjadi 4 bagian yaitu penyuluhan, kunjungan lapang, konsultasi lapang dan praktek keterampilan.

a. Penyuluhan. Para kelompok tani akan diberikan penyuluhan tentang teknik pascapanen terong virus dan teknik pengolahan jus terong virus. Kegiatan penyuluhan meliputi ceramah dan diskusi di dalam Balai Pertemuan. Pada kegiatan ini terjadi alih pengetahuan dari penyuluh kepada kelompok sasaran. Oleh karenanya dalam kegiatan ceramah dan diskusi peserta dibekali modul dari kegiatan yang akan dilaksanakan. Apabila dari model dan penjelasan lisan masih ada hal-hal yang belum jelas dapat ditanyakan pada saat diskusi. 
b. Kunjungan Lapang. Kunjungan ini akan dilakukan oleh Tim dari Unja bersama-sama dengan para petani ke lokasi pertanaman terong virus. Petani mendapatkan penjelasan tentang cara panen dan teknik penanganan terong virus segar sebelum diolah.

c. Konsultasi. Setelah kegiatan praktek dilakukan kunjungan kembali untuk melihat kelanjutan kegiatan dan sekaligus untuk mengatasi kesulitan para peserta tentang materi yang diberikan. Dalam kegiatan ini kelompok sasaran dilibatkan secara langsung sehingga dapat belajar sambil bekerja.

d. Praktek Keterampilan. Praktek teknologi pengolahan jus terong virus dilaksanakan di Balai Desa. Pertemuan oleh Tim Kegiatan memperagakan cara pembuatan jus terong virus. Selanjutnya para peserta diminta untuk mempraktekkan teori yang mereka dapatkan.

\section{HASIL YANG DICAPAI}

Kegiatan pengabdian dibagi menjadi 4 bagian yaitu penyuluhan, kunjungan lapang, konsultasi lapang dan praktek keterampilan.

a. Penyuluhan. Para kegiatan kelompok tani akan diberikan penyuluhan mulai dari pemahaman tentang konsep agroindustri terong virus, konsep pengembangan untuk meningkatkan pendapatan, teknik pascapanen terong virus dan teknik pengolahan jus terong virus. Kegiatan penyuluhan meliputi ceramah dan diskusi di dalam rumah salah seorang peserta, karena belum tersedianya tempat pertemuan yang permanen. Pada kegiatan ini terjadi alih pengetahuan dari penyuluh kepada kelompok sasaran. Oleh karenanya dalam kegiatan ceramah dan diskusi peserta dibekali modul dari kegiatan yang akan dilaksanakan. Apabila dari model dan penjelasan lisan masih ada hal-hal yang belum jelas dapat ditanyakan pada saat diskusi.

b. Kunjungan Lapang. Kunjungan ini dilakukan oleh Tim pengabdian bersama-sama dengan para petani ke lokasi pertanaman terong virus. Petani dijelaskan tentang cara panen dan teknik penanganan terong virus segar sebelum diolah. Perlu diketahui bahwa pada umumnya mereka kebanyakan menjual terong virus nya dalam keadaan terong virus segar atau belum diolah, karena mereka disamping perlu mendapatkan uang secepatnya, disamping itu sebagian peserta ada yang telah ada kesepakatan penjualan dengan pedagang lokal.

Kegiatan kunjungan lapang ini juga dibekali dengan memberikan wawasan mengenai konsep manajemen, dimana untuk menghasilkan kegiatan yang diinginkan sebaiknya fungsi manajemen berupa fungsi perencanaan, fungsi organisasi, fungsi pelaksanaan dan fungsi pengendalian harusnya dipahami dalam rangka untuk mendapatkan hasil yang lebih baik. Beberapa contoh yang telah disiapkan oleh tim mengenai agroindustri jus terong virus yang baik juga diperkenalkan, sehingga diharapkan mereka lebih aktif dan lebih memahami mengenai manfaat agroindustri jus terong virus. Sebagai gambaran, jika mereka menjual terong virus dalam keadaan segar atau baru dipanen dari lapangan, harga yang mereka peroleh jauh dibawah harga kalau mereka mengolah dan mengubah terong virus segar menjadi jus terong virus.

c. Konsultasi. Setelah kegiatan praktek dilakukan kunjungan kembali untuk melihat kelanjutan kegiatan dan sekaligus untuk mengatasi kesulitan para peserta tentang materi yang diberikan. Dalam kegiatan ini kelompok sasaran dilibatkan secara langsung sehingga dapat belajar sambil bekerja. Kegiatan konsultasi ini sekaligus untuk melihat seberapa besar 
antusias peserta dalam mengikuti kegiatan pengabdian ini. Dari hasil kegiatan sejauh ini, banyak peserta cukup antusias dan berperan aktif untuk bertanya seputar pemahaman tentang aspek agroindustri jus terong virus.

d. Praktek Keterampilan. Praktek pengolahan jus terong virus menjadi fokus kegiatan utama. Tahapan ini dilakukan untuk memperagakan cara pembuatan jus terong virus. Selanjutnya para peserta diminta untuk mempraktekkan teori yang mereka dapatkan, baik mengenai manajemen agribisnis terong virus maupun agroindustri jus terong virus. Setelah kegiatan ini berakhir akan dilakukan kegiatan post test yang berguna untuk melihat manfaat dari kegiatan pengabdian ini buat mereka. Dan hasil ini juga sekaligus untuk menindak lanjuti kegiatan berikutnya, jika ternyata kegiatan pengabdian ini bisa dijadikan salah satu solusi untuk pengembangan agribisnis dan agroindustri jus terong virus.

\section{Evaluasi Pelaksanaan Pengabdian Kepada Masyarakat}

Dalam pelaksanaan pengabdian kepada masyarakat dilakukan evaluasi untuk melihat seberapa jauh kegiatan ini manfaatnya bagi petani terong virus, maupun tim pengabdian. Dalam melaksanakan evaluasi, untuk mengetahui perubahan pengetahuan dilaksanakan evaluasi awal, observasi lapang dan evaluasi akhir. Evaluasi awal dilakukan sebelum kegiatan dimulai, dengan menggunakan seperangkat daftar pertanyaan mengenai tanaman terong virus dan teknologi pascapanennya. Dari evaluasi awal diperoleh hasil bahwa pengetahuan peserta pengabdian dalam pengenalan materi penyuluhan cukup baik, ini ditandai dengan rata-rata skore yang diperoleh sebesar $78 \%$ dari peserta mengetahui budidaya dan pascapanen terong virus. Hal ini memudahkan bagi tim pengabdian untuk melaksanakan pengabdian. Dari hasil observasi lapang juga menunjukkan bahwa pengetahuan peserta baik teknis budidaya dan teknologi pascapanen terong virus cukup baik. Dari hasil observasi lapang terlihat bahwa peserta cukup tanggap dalam mengikuti kegiatan penyuluhan. Terutama terlihat pada saat penyampaian materi melalui diskusi, banyak peserta ingin lebih jauh mengenal budidaya terong virus, teknologi pascapanen, maupun prospek jus terong virus secara keseluruhan. Dari tingkat kemajuan kegiatan ini dapat dilihat dari tingkat kehadiran peserta dalam mengikuti kegiatan penyuluhan ini. Dari tingkat kehadiran menunjukkan bahwa peserta cukup antusias dalam mengikuti kegiatan ini walaupun ada peserta yang menomorsatukan kegiatan ini dibandingkan dengan kegiatan rutin lainnya.

Perlu pula ditambahkan bahwa keberhasilan ini secara keseluruhan merupakan upaya bagaimana meningkatkan motivasi masyarakat pedesaan terutama petani terong virus untuk mempelajari dan sekaligus mengetahui bagaimana melakukan budidaya terong virus dan teknologi pascapanen jus terong virus dalam rangka untuk meningkatkan pendapatan mereka.

\section{Evaluasi Kelayakan Usaha Jus Terong Virus}

Kelayakan usaha dapat digunakan untuk memberikan tambahan informasi bagi petani terong virus untuk meningkatkan kinerjanya untuk melakukan agribisnis dan agroindustri terong virus yang efektif dan efisien. Evaluasi ini didasarkan dari berapa besar penerimaan yang diperoleh setelah menghitung setelah biaya yang dikeluarkan. Dengan kata lain evaluasi ini berguna melihat berapa besar keinginan petani terong virus untuk berusahatani yang baik. 
Umumnya petani tidak begitu paham maksud dari evaluasi kelayakan usaha Jus terong virus. Dari hasil penelitian produksi terong virus yang dihasilkan dan biaya yang dikeluarkan selama satu bulan adalah sebagai berikut. Produksi yang dihasilkan selama sebulan untuk menghasilkan terong virus kualitas super setara dengan 13 buah, sementara produksi untuk satu bulan sebanyak $75 \mathrm{~kg}$ dan harga $1 \mathrm{~kg}$ untuk terong virus super sebesar Rp. 8.000. Jadi penerimaannya selama sebulan sebesar Rp. 600.000. Sementara biaya yang dikeluarkan sebesar Rp. 225.000 untuk membeli keperluan pertumbuhan dan upah pemeliharaan.. Maka disamping besarnya pendapatan usahatani terong virus untuk sebulan sebesar Rp Rp. 375.000,- juga mempunyai makna kelayakan usaha terong virus untuk lokasi kegiatan pengabdian sebesar 2,67 yang berarti setiap pengeluaran usahatani sebesar Rp. 10,akan memberikan penerimaan sebesar Rp. 26,7,-

\section{KESIMPULAN}

Dari hasil kegiatan pengabdian kepada masyarakat ini dapat disimpulkan sebagai berikut : (a). Upaya peningkatan pendapatan petani terong virus dapat dilakukan dengan penerapan teknologi agroindustri jus terong virus dengan mengolah terong virus menjadi jus terong virus. (b). Memotivasi peserta kegiatan untuk mengetahui budidaya terong virus dan teknologi pascapanen terong virus ini cukup baik, yang ditandai dengan peningkatan evaluasi akhir dari evaluasi akhir dengan tingkat perbedaan yang nyata (c) kelayakan usaha untuk agroindustri terung virus sebesar 2,67.

\section{DAFTAR PUSTAKA}

Awang, 2013. Terong Virus Kajian Sosial Ekonomi. Penerbit Aditya Media, Yogyakarta Bappeda Tk.I Jambi, 2016. Membangunan Jambi menjadi Prototipe Provinsi Otonom. Bappeda Tk.II Kerinci, 2016. Laporan Tahunan Bappeda Tk. II Kerinci.

Dinas Pertanian Tanaman Pangan Daerah Tingkat I Jambi. 2016. Laporan Tahunan. Jambi. Edison, 2013. Pengembangan Agribisnis dan Agroindustri Keripik Kentang di Kerinci, Fakultas Pertanian Universitas Jambi, Jambi.

Firwan, T. 2004. Pengembangan Industri Berbasis Produksi Pertanian. Makalah Disampaikan pada Seminar Pembangunan Daerah Kerinci, Kerinci.

Helmi, 2008. Aspek Kelembagaan dalam Menciptakan Sinergi diantara Pemerintah, Masyarakat dan Pasar. Makalah disampaikan pada Seminar Nasional Ketahanan Pangan dan Agribisnis, di Padang.

Renate, D. 2004. Pengolahan Keripik Kentang Rasa Asam. Laporan Penelitian Unja. Jambi. Samadi, B. 2004. Usahatani Kentang. Penerbit Kanisius, Yogyakarta.

Saragih, B. 2013 Peranan Teknologi Tepat Guna dalam Pengembangan Sistim Agribisnis Kerakyatan dan Berkelanjutan. Makalah dalam Seminar II Teknologi Tepat Guna. Bandung.

Soeharjo, A. 2006. Agroindustri, Industrialisasi Pedesaan dan Transportasi Pedesaan dalam Simposium Industrialisasi Pedesaan PS Pembangunan LP-IPB Bogor.

Sudaryanto, T. dan E. Jamal. 2005. Pengembangan Informasi dan Teknologi Pertanian Mendukung Ketahanan Pangan dan Agribisnis. Makalah disampaikan pada Seminar Nasional Ketahanan Pangan dan Agribisnis, di Padang.

Soekartawi, 2006. Agribisnis: Teori dan Aplikasinya, PT Raja Grafindo Persada, Jakarta. 
Jurnal Karya Abdi Masyarakat

Volume 2 Nomor 1 Januri - Juni 2018

Susanti, E. 2003. Teknologi Agroindustri, Industrialisasi Pedesaan dan Transportasi Komoditi Hortikultura , Studi Kasus pada Komoditi Hortikultua di Kabupaten Kayu Aro, Kerinci, Jambi

Susanto, T dan B. Saneto. 2003. Teknologi Pengolahan Hasil Pertanian. PT. Bina Ilmu. Surabaya

Taher, A. 2003. Strategi Pengembangan Inoformasi dan Teknologi Untuk Ketahanan Pangan dan Agribisnis, Ditinjau dari Aspek Teknik Produksi dan Alih Teknologi. Makalah disampaikan pada Seminar Nasional Ketahanan Pangan dan Agribisnis, di Padang 